\title{
CBCT IS THE BETTER INVESTIGATING TOOL FOR THE FACIAL RECOGNITION FOR FORENSIC IDENTIFICATION: A SYSTEMATIC REVIEW
}

KEY WORDS: CBCT ,Facial recognition, facial reconstruction ,forensic odontology.

\section{Dr.Jijin \\ Mekkadath \\ Jayakrishnan*}

\section{Dr.Jagat Reddy}

\section{Dr.Vinod Kumar R.B}

MDS,PH.D Scholar, Dept. Of Oral Medicine And Radiology, Sri Balaji Vidyapeeth, IGIDS, Puducherry. *Corresponding Author

Guide And Professor And Head , department Of Oral Medicine And Radiology Indiragandhi Institute Of Dental Science, Sri Balaji Vidhyapeeth University Pillaiyarkuppam, Puducherry-607403.

Co-guide, Pricipal\& Head , Department Of Oral Pathology And Microbiology, MDC ,Edappal, Kerala.

Background: Forensic facial reconstruction is a combination of both artistic skill and scientific methods. It can be used to
reconstruct the soft tissues onto the skull in order to obtain the image of an individual for her/his recognition and
identification. Some reviewers considered that forensic facial reconstruction is a method of facial approximation, i.e.
various facial patterns can be established from the same skull.
Main body: The review aimed to describe CBCT is the better investigating tool for the facial recognition for forensic
identification A search in PubMed, Google Scholar, and Scopus electronic databases from 2010 to 2020 was conducted to
include studies according to PRISMA guidelines. 12 studies were eligible for the review.
Conclusions: Cone beam CT images of the face using routine scanning protocols are a reliable method of measuring
the soft tissue thickness in the facial region and give a good representation of the facial soft tissues.

\section{INTRODUCTION}

Craniofacial reconstructionis a forensic technique that recreates an individual's face from a skull for human identification. $^{[1]}$ Facial bones and teeth are the most resilient structures in the human body that can withstand the destructional and decompositional forces even under extreme forces and/or temperature. Human teeth have been utilized for determining the gender especially in cases where there are no physical evidences to arrive at an individual's identity. The main purpose of any forensic facial approximation is to recreate the face of a deceased individual at the time of death based on his/her skull. The most extensive and detailed post-mortem data are useless without any link to the ante-mortem data. In these cases, forensic facial approximation can be considered as a last resort to identify the deceased. ${ }^{[1]}$

Forensic facial reconstruction is a combination of both scientific methods and artistic skill. It can be used to reconstruct the soft tissues onto the skull in order to obtain the image of an individual for his/her recognition and identification. Some reviewers consider forensic facial reconstruction as a method of facial approximation, i.e. various facial patterns can be established from the same skull. On the other hand, some researchers felt that each skull can only produce one face and this would hence lead to positive identification of an individual and they used the term "Facial Reconstruction., ${ }^{[2]}$

Comparative identification is employed in all such situations wherein the post-mortem data of the deceased is matched with his preexisting medical and dental records, the method is of limited use in the absence / unavailability of antemortem details. Even biological identification through DNA necessitates a known profile for comparison. In all such circumstances when the investigation process reaches a blind end, forensic experts retreat to craniofacial reconstruction, an anthropological technique which aids in the identification of the deceased through recognition by the public. ${ }^{[3]}$

\section{METHODS}

\section{Study protocol}

Ethical approval from the Institutional review board was obtained The present study was conducted following the
Preferred Reporting Items for Systematic Reviews and MetaAnalyses (PRISMA) guidelines. ${ }^{[4]}$

\section{Search strategy}

A systematic search was performed in PubMed/MEDLINE, Scopus, and Google Scholar databases for the period 2010-2020. The keywords for the search included CBCT ,facial recognition, facial reconstruction and forensic odontology.

\section{Eligibility criteria}

Only the studies reporting the utilization of CBCT in facial recognition and facial reconstruction over the past 10 years (2009-2019) published in English language were included in the current systematic review. Articles were screened by title and abstract, and then possible inclusion of full article was selected. Studies without abstract, abstract without full paper ,reviews, case-reports and short communication articles were excluded from our study.

\section{Data collection}

The articles were first screened in accordance with the abovementioned keywords in their title and abstract. The second screening was performed based on the inclusion and exclusion criteria to find relevant full-text articles and the eligible articles were selected. The full text articles were read and assessed by individual reviewers independently to regain relevant data for review.

\section{RESULTS \\ LITERATURE SEARCH AND SCREENING}

The selection process of the study screening protocol is shown in Fig. 1. A total number of 375 articles were retrieved, out of which 95 were duplicates, leaving 280 articles for screening. Of these, 125 articles were excluded by titles and abstracts, leaving 155. After full-text screening, only 12 articles were found to be eligible for our systematic review. The procedure of the selection process is presented in Fig. 1.

\section{Data extraction}

The data of each article, including the name of the first author, year of publication, sample size,study design, age group (years old), out come were extracted and are listed in Table 1. 
CBCT is the better investigating tool for the facial recognition for forensic identification findings:

Among the 12 studies included, nine studies reported about facial soft tissue thickness(Zacharias fourie et-al2010; Hyeonshik hwang et-al2012;Natalia zamora et-al2012;Hyeonshikhwang et-al20l2; Marcelo baiaodaneiva etal2014; Hyeon-shikhwang et-al2015;manasaanandmeundi etal2019; chuweideng et-al2020; amandafariasgomes etal2020) and two studies reported nasal morphology(Kyungmin lee et-al2013; guang-chu et-al2020)and onestudy reported on human eyeball and canthi(sang-rokkim etal2016). Out of 12 studies, 11 studies reported the subject age between 8-80 years (Hyeon-shikhwang et-al2012;Natalia zamora et-al2012;Hyeon-shikhwang et-al2012; Marcelo baiaodaneiva et-al2014;Hyeon-shikhwang etal2015; manasaanandmeundi et-al2019; chuweideng etal2020;amandafariasgomes et-al2020;Kyung-min lee etal2013; guang-chu et-al2020sang-rokkim et-al2016;); the study by Zacharias et al using cadavers for their study did not mention the age group (Zacharias fourie et-al2010). The facial soft tissue thickness studiesreported maximum 34 land marks with a field of view $200 * 170 \mathrm{~mm}$.

In the current review, it was observed that only three studies were gender specific and considered male and female subjects(Hyeon-shikhwang et-al2012;Kyung-min lee etal2013;sang-rokkim et-al2016), while other studies did not specify the gender. Eleven studies the included in the study were prospective type while one retrospective in nature (Zacharias fourie et-al2010)

\section{DISCUSSION}

Cone beam CT(CBCT) allows images to be obtained with the subject in an upright position. It provides a natural shape of the facial mask as the subject can be scanned in the seated position ${ }^{[5]}$. Several studies have employed CBCT scanning to analyze the relationship between the skeletal nasal bone and external nose morphology in different populations ${ }^{[6]}$. Zacharias fourie et-al,2010 conducted a study to assess accuracy and reliability of facial soft tissue depth measurements using CBCT. The study showed that CBCT images of the face using routine scanning protocols are reliable for measuring soft tissue thickness in the facial region and give an honest representation of the facial soft tissues. For more accurate data collection the $0.3 \mathrm{~mm}$ voxel size should be considered ${ }^{[1]}$ Numerous facial approximation studies about soft tissue thickness are produced to supply guidance on profile prediction.

However, little guidance exists for prediction of interrelationship between the hard and soft tissues of the face using CBCTimages.(7) The CBCT scans are obtained with the utilization of reference ear plug (REP) and head posture aligner (HPA) . The REP, which contains a $1.0 \mathrm{~mm}$ diameter titanium ball marker in its center, inserted into each subject's external auditory meatus, hence the two ball markers are often represented on 3D volume rendering image. The HPA, which contains fluid level equalizer with a pivot form and wire indicator, placed on the patient's left zygoma area and which adjusted the fluid level equalizer register the degree of vertical head rotation at natural head position ${ }^{[7]}$. Stephan et al.examined four published and commonly used soft tissue prediction guidelines for estimating nose projection and pronasale position. With an adjustment of Hounsfield scales of the CBCT images because the function of bone and soft tissue within the software, the hard and soft tissue images are often evaluated simultaneously. ${ }^{[7]}$. Statistically significant regression models for the $3 \mathrm{D}$ positions of the eyeball and canthi might be derived from the measurements of the orbit and upper canine. CBCT data are often useful for predicting the positions of the eyeball and canthi three-dimensionally. ${ }^{[5]}$ The position, size, shape, and proportions of the nose provide visual bases for the facial character of the person, which successively facilitates face recognition. In forensic science, the estimation of external nose morphology may be a crucial issue that might help identify people supported skulls. to the present regard, the investigation of external nose morphology supported CBCT and 3dMD images in living subjects may provide further help to forensic anthropologists. ${ }^{[6]}$

most of the hard tissue measurement (nasal width, nasal height, nasal length, alare angle, nasal tip angle, rhinion protrusion, nTr-rhiTr, rhiTr-alTr, nTr-alTr, rhiTr-nsTr, and nTrnsTr) were significantly different between males and females, apart from the nasal dorsum angle, nasolabial angle, nasospinale protrusion, and alTr- nsTr. altogether of the measurements with significant differences, the males showed higher values compared to the females, apart from the alare angle and nasal tip angle. . However, the soft-tissue measurement values indicate that Nasal bridge length, Nasal height, Nasal columella length, Alar width, Alare angle, and Nasal tip protrusion were significantly different between males and females. . However, in terms of Basis nasi angle, Nasal dorsum angle, Nasal tip angle, Nasolabial angle, and Basis nasi protrusion, no significant differences were observed between the sexes. In terms of sentimental tissues, the males showed higher values compared to the females. ${ }^{[6]}$

CBCT images of the face using routine scanning protocols are a reliable method of measuring the soft tissue thickness within the facial region and provides an honest representation of the facial soft tissues. Farman et al. reported that the soft tissue definition with CBCT is sufficient to figure out air/soft boundaries, including the patient's lateral profile, greater clarity of sentimental tissue definition could improve the assessment of bulk and insertion patterns of the maxillofacial musculature .Moerenhout et al. used phantom heads to figure out the 3D surface accuracy of sentimental tissue acquired form a CBCT scan of a mannequin head and using two commercial 3D image processing software programs. They found that 3D surface of the facial soft tissues segmented and reformatted form a CBCT scan proved to be accurate .Heyland et al. stated that integration of flat panel detectors in mole CBCT systems results in an improved visualization of sentimental tissues in cadavers . СВCT visualizes highcontrast in sufficient quality with a stimulating low level of metal artefacts. However, they stated that the image quality of corresponding CT and MRI proved to be superior in most of the evaluated criteria. ${ }^{[1]}$

The facial ST thickness measurements on the CBCT images showed high inter- and intra-observer reproducibility. The CBCT images are often used reliably for the aim of facial reconstruction. While some landmarks showed low reproducibility, the reliability may be increased by redefining the landmarks according to the characteristics of the 3D images. ${ }^{[8]}$

In ' Morphometric analysis of facial soft tissue thickness for sexual dimorphism A cone beam study', Measured data was analysed on the basis of age and sex. STT was compared at five progressive age groups within an equivalent sex and between sexes. Variations in STT with advancing age was negligibly small within the same gender. However, the values vary significantly between the genders. In the regions around the upper lip (midphiltrum, labralesuperius, supracanine), the differences were significant at all age groups whereas at areas around the cheek and the mandible (supraM2, infraM2, gonion, mid ramus and mid mandibular border), the differences were significant only beyond $40 \mathrm{yrs}$. Since the age and sex of the skull will be assessed prior to the start of the reconstruction process, these observations may be utilised for improved results. Wilkinson observed no definite relation within the STT values and therefore the advancing age although there's a trend of decrease in STT round the mouth and cheek areas while STT being increased at the chin as age advances. 15 Similar pattern is observed in the current study which is noticeable evidently in females than in males. 
explored facial soft tissue thickness of male and female at different age groups and evaluated the statistical significance of STT measurements between the genders at different age groups. Results of the analysis show sexual dimorphism with a significantly higher STT in males of all ages than in females. In both men and women, there is an increasing trend in STT values noted at all the points with advancing age. Facial soft tissue thicknesses were lower in the regions of upper face and chin while its larger in the regions around the mandible. ${ }^{[3]}$

Acording to some authors who studied the symmetry of the skull, it was found that in skulls with perfect symmetry the mandible must respond to geometric triangulation; in "A new 3D method for measuring cranio-facial relationships with cone beam computerized tomography (CBCT)" study they examinated the mandible as a triangle (CdR-Me-CdL) of an equilateral type whose sides must be equal..$^{[9]}$

In the case of bilateral landmarks, 12 of 21 sites showed statistically significant sex differences. While the majority presented greater values in male subjects, such as the midline landmarks, the lateral orbit that corresponds to the zygoma area showed a smaller value in male subjects than in female subjects. This indicates that the ST over the zygoma area is thinner in men than in women, unlike the majority of the face .No significant differences were found between the right and left ST thickness measurements at all landmarks of the face. The relative bilateral differences showed higher values at the lower face, including the masseter muscle area.$^{[10]}$

The most widely used software in studies was Dolphin 3D (Dolphin Imaging and Management Systems, Chatsworth, Calif), which reinforces the need for resource assessment of other commercial software for clinical use, such as the InVivo $\mathrm{N}$ The frequency of highly reliable values in the identification of cephalometric landmarks using CBCT was greater in the visualization of multiplanar than in 3D image reconstructions, and it had been also higher in intraobserver than in interobserver analyses. $\mathrm{N}$ generally, the landmarks on the condyle were people who generated lower reliability; higher reliability was found for those on the midsagittal plane. Depending on the anatomic region, the observer must choose the more reliable type of image visualization. ${ }^{[1]}$.

The ST thickness measurements using CBCT images show the highest reproducibility when they are obtained by "perpendicular to bone" method. The reason for higher interobserver reproducibility of "perpendicular to bone" method than that of "perpendicular to skin" method seems to lie in clearness of landmark definitions. Anatomical structures are easily identified on hard tissues, whereas a landmark is not identified easily on soft tissue surface. ${ }^{[12]}$.

the sex and BMI had a wide impact on FSTT, and the influence

Table 1

\begin{tabular}{|l|l|l|l|l|l|l|}
\hline $\begin{array}{l}\text { sl } \\
\text { no }\end{array}$ & Author & year & $\begin{array}{l}\text { sample } \\
\text { size }\end{array}$ & age group & $\begin{array}{l}\text { study } \\
\text { design }\end{array}$ & out come \\
\hline 1 & $\begin{array}{l}\text { Zacharias } \\
\text { fourie et-al }\end{array}$ & 2010 & 7 & N/A & $\begin{array}{l}\text { retrosp } \\
\text { ective } \\
\text { study }\end{array}$ & $\begin{array}{l}\text { Cone beam CT images of the face using routine scanning protocols } \\
\text { are reliable for measuring soft tissue thickness in the facial region } \\
\text { and give a good representation of the facial soft tissues. For more } \\
\text { accurate data collection the 0.3 mm voxel size should be considered. }\end{array}$ \\
\hline 2 & $\begin{array}{l}\text { Hyeon-shik } \\
\text { hwang et-al }\end{array}$ & 2012 & 20 & $20.1-33.6$ yrs & $\begin{array}{l}\text { prospe } \\
\text { ctive } \\
\text { study }\end{array}$ & $\begin{array}{l}\text { The results of this study indicate that CBCT images can be used to } \\
\text { measure ST thickness with high reproducibility. However, some } \\
\text { landmarks need to be redefined to reliably measure ST thickness on } \\
\text { CBCT images. }\end{array}$ \\
\hline 3 & $\begin{array}{l}\text { Natalia } \\
\text { zamora et-al }\end{array}$ & 2012 & 90 & $8-50$ yrs & $\begin{array}{l}\text { prospe } \\
\text { ctive } \\
\text { study }\end{array}$ & $\begin{array}{l}\text { When analyzing the sides of the CdR-Me-CdL triangle, it was found } \\
\text { that the 69.33\% of the patients could be considered symmetric.: A } \\
\text { new method for assessing } \\
\text { cranio-facial relationshps using CBCT has been established. It could } \\
\text { be used for diverse purposes including diagnosis and treatment } \\
\text { planning. }\end{array}$ \\
\hline 4 & $\begin{array}{l}\text { Hyeon-shik } \\
\text { hwang et-al }\end{array}$ & 2012 & 100 & $\begin{array}{l}\text { male:20.2-36.1 } \\
\text { yrs female:20- } \\
35.2 \text { yrs }\end{array}$ & $\begin{array}{l}\text { prospe } \\
\text { ctive } \\
\text { study }\end{array}$ & $\begin{array}{l}\text { Using the CBCT scan images of Korean adults, the means and } \\
\text { standard deviations of the facial ST thickness were obtained to } \\
\text { enable forensic facial reconstruction. }\end{array}$ \\
\hline
\end{tabular}

$\mid$ www.worldwidejournals.com $\mid$ of age mainly reflected in the oral region in females. Additionally, most of the significant landmarks related to malocclusion types were located in the oral region. The validation testing revealed that measurement method cannot be ignored as an influential factor. ${ }^{[13]}$

There was a soft tissue compensation in skeletal areas with lower skeletal development and/or where bone is positioned more posteriorly, i.e., class III individuals had thicker soft tissue in regions of the maxilla, while class II subjects had thicker soft tissue in regions of the mandible. A similar tendency was observed for facial types, in which dolichocephalic individuals showed thicker soft tissue in regions of the mandible, and brachycephalic had thicker soft tissue in regions of the maxilla. ${ }^{[14]}$

The superimposition of CBCT and 3dMD images is a reliable method in nasal morphology reconstruction. Cone beam CT images of the face using routine scanning protocols are a reliable method of measuring the soft tissue thickness in the facial region and give a good representation of the facial soft tissues. The data confirmed that CBCT soft tissue measurements can be used to create a database of soft tissue thickness. The $0.3 \mathrm{~mm}$ slice thickness gives an accurate data collection of the soft tissue. There is a slight but definite difference in the facial soft tissue thickness measurements. For more fine and accurate data collection of the facial soft tissue thickness form the CBCT, the 0.3 voxel size scan is recommended. ${ }^{[14]}$

One of the limitation of the study is CBCT is expensive and its not available in all places. In future more artificial intelligence and machine learning easy to access the facial recognition.

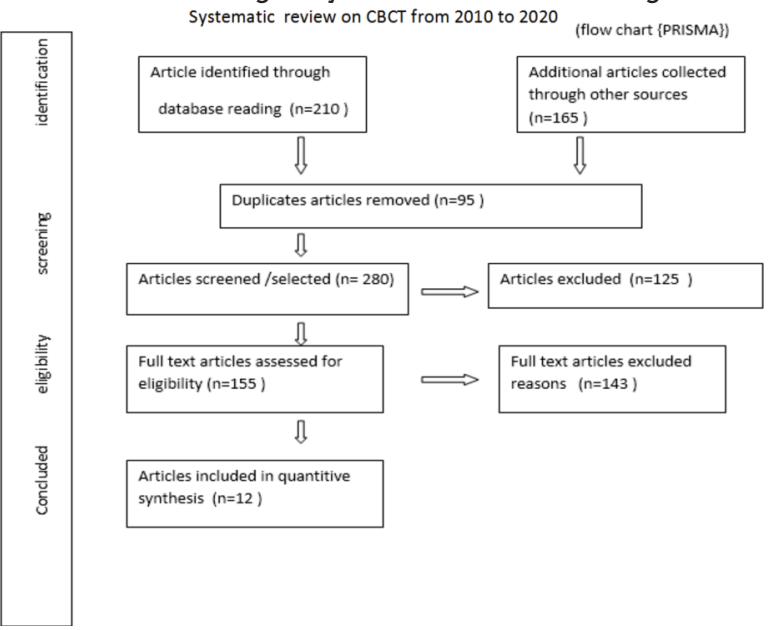

Fig.1 


\begin{tabular}{|c|c|c|c|c|c|c|}
\hline 5 & $\begin{array}{l}\text { Kyung-min lee } \\
\text { et-al }\end{array}$ & 2013 & 60 & $\begin{array}{l}\text { male:29.6( } \\
\text { mean) } \\
\text { female:28. } \\
2\{\text { mean\} }\end{array}$ & $\begin{array}{l}\text { prospective } \\
\text { study }\end{array}$ & $\begin{array}{l}\text { These results suggest that hard and soft tissue relation data from } \\
\text { CBCT can be useful for predicting the position of nose. }\end{array}$ \\
\hline 6 & $\begin{array}{l}\text { Marcelo } \\
\text { baiaoda neiva } \\
\text { et- al }\end{array}$ & 2014 & 12 & $20-43$ yrs & $\begin{array}{l}\text { prospective } \\
\text { study }\end{array}$ & $\begin{array}{l}\text { The frequency of highly reliable values was greater for } \\
\text { multiplanar than 3D reconstructions. }\end{array}$ \\
\hline 7 & $\begin{array}{l}\text { Hyeon-shik } \\
\text { hwang et-al }\end{array}$ & 2015 & 20 & $\begin{array}{l}27.6 \\
\text { yrs }\{\text { mean }\}\end{array}$ & $\begin{array}{l}\text { prospective } \\
\text { study }\end{array}$ & $\begin{array}{l}\text { The results indicate that reproducibility could be increased by } \\
\text { identifying the landmarks on hard tissue images, rather than on } \\
\text { ST images, and the landmark description used in this study can } \\
\text { be used in the establishment of reliable tissue depth data using } \\
\text { CBCT images. }\end{array}$ \\
\hline 8 & $\begin{array}{l}\text { sang-rok kim } \\
\text { et-al }\end{array}$ & 2016 & 100 & $\begin{array}{l}\text { women }\{23 \\
-30.2\} \\
\text { male }\{25.3- \\
31.1\}\end{array}$ & $\begin{array}{l}\text { prospective } \\
\text { study }\end{array}$ & $\begin{array}{l}\text { These results suggest that CBCT data can be useful in } \\
\text { predicting the positions of the eyeball and canthi three- } \\
\text { dimensionally. }\end{array}$ \\
\hline 9 & $\begin{array}{l}\text { manasa anand } \\
\text { meundi et-al }\end{array}$ & 2019 & 307 & $18-80$ yrs & $\begin{array}{l}\text { prospective } \\
\text { study }\end{array}$ & $\begin{array}{l}\text { Present study has provided mean facial soft tissue thickness } \\
\text { values of adult south Indian population at suitable reference } \\
\text { points. The derived discriminant function equations will be } \\
\text { useful in sex determination of the unknown. STT along with their } \\
\text { age and sex related variations will be valuable in forensic facial } \\
\text { reconstructions, plastic surgeries and in anthropology. }\end{array}$ \\
\hline 10 & $\begin{array}{l}\text { chuwei deng } \\
\text { et-al }\end{array}$ & 2020 & 424 & $21-50$ yrs & $\begin{array}{l}\text { prospective } \\
\text { study }\end{array}$ & $\begin{array}{l}\text { The results of this research established the detailed facial } \\
\text { approximation database of Yangtze River delta Han population } \\
\text { using CBCT. }\end{array}$ \\
\hline 11 & $\begin{array}{l}\text { guang-chu et- } \\
\text { al }\end{array}$ & 2020 & 240 & $20-30$ yrs & $\begin{array}{l}\text { prospective } \\
\text { study }\end{array}$ & $\begin{array}{l}\text { study proved that a combined CBCT and 3dMD } \\
\text { photogrammetry system is a reliable method for nasal } \\
\text { morphology estimation. Further research should investigate } \\
\text { other influencing factors such as age, skeletal types, facial } \\
\text { proportions, or population variance in nasal morphology } \\
\text { estimation. }\end{array}$ \\
\hline 12 & $\begin{array}{l}\text { amanda farias } \\
\text { gomes et-al }\end{array}$ & 2020 & 121 & $21-40$ yrs & $\begin{array}{l}\text { prospective } \\
\text { study }\end{array}$ & $\begin{array}{l}\text { specific soft tissue thickness be used for each skeletal class and } \\
\text { facial type at the points that differed significantly, and mean } \\
\text { values for the points that did not differ, in order to obtain more } \\
\text { reliable facial reconstructions in the Brazilian population. }\end{array}$ \\
\hline
\end{tabular}

\section{REFERENCES}

1. Fourie Z, Damstra J, Gerrits PO, Ren Y. Accuracy and reliability of facial soft tissue depth measurements using cone beam computer tomography. Forensic Sci Int.2010 Jun;199(1-3):9-14.

2. Gupta S. Forensic Facial Reconstruction: The Final Frontier. J Clin Diagn Res [Internet].2015 [cited 2020 Dec 31];

3. Manasa Anand Meundi, Chaya M David: Morphometric analysis of facial soft tissue thickness for sexual dimorphism $A$ cone beam;IP International Journal of Forensic Medicine and Toxicological Sciences, April-June, 2019;4(2):60-67

4. Moher D, Liberati A, Tetzlaff J, Altman D ; Preferred Reporting Items for Systematic Reviews and Meta-Analyses: the PRISMA statement. Ann Intern Med (2009) 151:264-269.

5. Kim S-R, Lee K-M, Cho J-H, Hwang H-S. Three-dimensional prediction of the human eyeball and canthi for craniofacial reconstruction using cone-beam computed tomography. Forensic Sci Int. 2016 Apr;261:164.el-164.e8.

6. Chu G, Zhao J, Han M, Mou Q, Ji L, Zhou H, et al. Three-dimensional prediction of nose morphology in Chinese young adults: a pilot study combining conebeam computed tomography and 3dMD photogrammetry system. Int J Legal Med.2020 Sep;134(5):1803-16.

7. Lee K-M, Lee W-J, Cho J-H, Hwang H-S. Three-dimensional prediction of the nose for facial reconstruction using cone-beam computed tomography. Forensic Sci Int. 2014 Mar;236:194.el-194.e5.

8. Hwang H-S, Kim K, Moon D-N, Kim J-H, Wilkinson C. Reproducibility of Facial Soft Tissue Thicknesses for Craniofacial Reconstruction Using Cone-Beam CT Images: FACIAL SOFT TISSUE THICKNESS USING CBCT IMAGES. J Forensic Sci. 2012 Mar;57(2):443-8.

9. Zamora N, Cibrian R, Gandia Jl, Paredes V. A new 3D method for measuring cranio-facial relationships with cone beam computed tomography (CBCT). Med Oral Patol Oral Cirugia Bucal. 2013;e706-13.

10. Hwang H-S, Park M-K, Lee W-J, Cho J-H, Kim B-K, Wilkinson CM. Facial Soft Tissue Thickness Database for Craniofacial Reconstruction in Korean Adults: FACIAL SOFT TISSUE THICKNESS DATABASE. J Forensic Sci. 2012 Nov;57(6):1442-7.

11. da Neiva MB, Soares ÁC, de Oliveira Lisboa C, de Vasconcellos Vilella O, Motta AT. Evaluation of cephalometric landmark identification on CBCT multiplanar and 3D reconstructions. Angle Orthod.2015 Jan;85(1):11-7.

12. Hwang H-S, Choe S-Y, Hwang J-S, Moon D-N, Hou Y, Lee W-J, et al. Reproducibility of Facial Soft Tissue Thickness Measurements Using ConeBeam CT Images According to the Measurement Methods.J Forensic Sci. 2015 Jul;60(4):957-65.

13. Deng C,Wang D, Chen J, Li K, Yang M, Chen Z, et al. Facial soft tissue thickness in Yangtze River delta Han population: Accurate assessment and comparative analysis utilizing Cone-Beam CT.Leg Med.2020 May;44:101693.

14. Farias Gomes A, Moreira DD, Zanon MF, Groppo FC, Haiter-Neto F, Freitas DQ. Soft tissue thickness in Brazilian adults of different skeletal classes and facial types:A cone beam CT-Study.Leg Med.2020 Nov;47:101743. 